The Fournal of Modern African Studies, 35, 2 (1997), pp. 207-229.

Printed in the United Kingdom (C) 1997 Cambridge University Press

\title{
The Anglophone Problem in Cameroon
}

\author{
by PIET KONINGS and FRANGIS B. NYAMNJOH*
}

Tне political agenda in Cameroon has become increasingly dominated by what is known as the 'anglophone problem', which poses a major challenge to the efforts of the post-colonial state to forge national unity and integration, and has led to the reintroduction of forceful arguments and actions in favour of 'federalism' or even 'secession'.

The root of this problem may be traced back to ig6I when the political élites of two territories with different colonial legacies - one French and the other British - agreed on the formation of a federal state. ${ }^{1}$ Contrary to expectations, this did not provide for the equal partnership of both parties, let alone for the preservation of the cultural heritage and identity of each, but turned out to be merely a transitory phase to the total integration of the anglophone region into a strongly centralised, unitary state. Gradually, this created an anglophone consciousness: the feeling of being 'marginalised', 'exploited', and 'assimilated' by the francophone-dominated state, and even by the francophone population as a whole.

It was not until the political liberalisation process in the early i 990 os that some members of the English-speaking élite started openly to protest against the supposed subordinate position of the anglophones and to lay claims for self-determination and autonomy. Whereas the most important organisations initially called for a return to the federal state, the persistent refusal of the Government headed by President Paul Biya to discuss any related constitutional reforms forced some to adopt a secessionist stand. They attempted to gain international recognition for their demands through a diplomatic offensive that

\footnotetext{
* Piet Konings is Senior Researcher at the Afrika-Studiecentrum, Leiden, and Francis Nyamnjoh is Senior Lecturer at the University of Buea, Cameroon.

${ }^{1}$ Other scholars trace the genesis of the anglophone problem in Cameroon to World War I. According to Nicodemus Awasom, 'The Development of Autonomist Tendencies in Anglophone Cameroon, I9I6-6I', the unequal partition of the country between France and Britain, following the defeat of Germany in West Africa in I9I6, 'sowed the seeds of future problems' in that this accounted for 'the ultimate emergence, in a reunified Cameroon, of an anglophone minority and a French majority'.
} 
presented the anglophones as an oppressed minority whose territory had been 'annexed' by the francophone-dominated state.

The Government has not surprisingly devised various strategies to safeguard the unitary state, including attempts to minimalise or even deny the existence of an 'anglophone problem', to create divisions among the English-speaking élite, to remunerate some allies with prestigious positions in the state apparatus previously reserved for francophones only, and to repress all actions designed to change the status of the Southern Cameroons.

THE GONSTITUTIONAL BAGKGROUND

The birth of the Federal Republic of Cameroon on i October ig6 I marked the reunification of two territories which had undergone different colonial experiences after World War I, ${ }^{2}$ when the erstwhile German Kamerun Protectorate was partitioned between the British and the French, first as 'mandates' under the League of Nations and later as 'trusts' under the United Nations. ${ }^{3}$ It needs to be recalled that part of the British mandate/trust territory, which came to be called Southern Cameroons, was initially attached to the Eastern Provinces of Nigeria until 1954, when it achieved a quasi-regional status and a limited degree of self-government within the Federation of Nigeria, where it attained full regional status in I958. There can be no doubt that the administration of Southern Cameroons as an appendage of Nigeria resulted in the blatant neglect of its development, ${ }^{4}$ as well as the dominant position of Ibo and Efik-Ibibio migrants in its economy.

\footnotetext{
${ }^{2}$ See, for instance, Willard R. Johnson, The Cameroon Federation: political integration in a fragmentary society (Princeton, NJ, I 970); Victor T. Le Vine, The Cameroon Federal Republic (Ithaca and London, I97I); and Jacques Benjamin, Les Camerounais occidentaux: la minorité dans un état bicommunautaire (Montreal, I972).

${ }^{3}$ See Edwin W. Ardener, 'The Political History of Cameroon', in The World Today (London), I8, 8, I962, pp. 341-50; David E. Gardinier, Cameroon: United Nations challenge to French policy (Oxford, I 963); Victor T. Le Vine, The Cameroons: from mandate to independence (Berkeley and Los Angeles, I 964); and Richard A. Joseph, Radical Nationalism in Cameroun: social origins of the U.P.C. rebellion (Oxford, I977).

${ }^{4}$ According to Paul M. Kale, Political Evolution in the Cameroons (Buea, Government Printer, I967), pp. I 2-I3, Britain's administration prior to World War II was 'haphazard and full of misgivings', provoked by 'an apparent lack of administrative interest' which he thinks was due to 'the fear that Germany might suddenly demand a return of her former African possessions'. For this reason, Britain might have thought it "preposterous spending, and possibly wasting, British taxpayers' money and talent on what was not, strictly speaking, a developing British country'. From Le Vine, op. cit. I 964 , pp. I 94-20 I, we gather that Whitehall often regarded Southern Cameroons 'as somewhat of a colonial liability', administered all the way from Lagos, with hope of its 'eventual integration with Nigeria'. It had neither a separate budget nor separate public accounts; all its government revenues were treated as part of a common fund.
} 
It was Southern Cameroons which voted in the I96 I United Nations plebiscite for reunification with French Cameroun rather than for integration into Nigeria. ${ }^{5}$

What was expected to mark the start of a unique federal experiment in Africa soon turned out to be 'more shadow than reality'. ${ }^{6}$ During negotiations on the constitution, particularly at the Foumban conference in July ig6r, the bargaining strength of the francophone delegation reflected the fact that the size and population of the anglophone region was small, comprising only nine per cent of the total area and about a quarter of the total population. And even more important, by the time of these negotiations, the Southern Cameroons had still to achieve its independence by joining the sovereign Republic of Cameroon, whose President, Ahmadou Ahidjo, as leader of the francophone delegation, was able to dictate the terms for federation by capitalising on his territory's 'senior' status. ${ }^{7}$ John Ngu Foncha, the Prime Minister of Southern Cameroons and leader of the anglophone delegation, had proposed a loose form of federalism but was eventually forced to accept a highly centralised system of government and administration. $^{8}$

${ }^{5}$ Concerning reunification, it is worth noting that in spite of a 'popular' disinclination for an 'early reunification after secession from Nigeria', the UN never gave the people that option. Also, the boundaries of the reunified territory 'were not willed by those who wished for reunification', but were imposed on them; consequently, they were much narrower than they would have been 'if a simple reconstruction of German Kamerun had been achieved'. See Edwin W. Ardener, 'The Nature of the Reunification of Cameroon', in Arthur Hazlewood (ed.), African Integration and Disintegration (Oxford, I967), pp. 285-337.

${ }^{6}$ Cf. Frank M. Stark, 'Federalism in Cameroon: the shadow and the reality', in Canadian Journal of African Studies (Ottawa), го, 3, г976, pp. 423-42.

7 This interpretation is not shared by everyone. V.J. Ngoh, for example, argues in Weekly Post (Yaoundé), 26-3 I July i 995, that John Ngu Foncha's 'relegation to the back seat' of the British authorities, 'who were expected to guide and give expert counsel to the KNDP [Kamerun National Democratic Party] during their negotiations with Ahmadou Ahidjo', was the real reason why the Southern Cameroons emerged as the loser.

${ }^{8}$ The members of the Southern Cameroons delegation had met in Bamenda in June I96 I to decide upon their own version of federalism for a unified Cameroon. Their proposals included, inter alia: (i) a separate government, (ii) a bicameral federal legislature, (iii) a ceremonial not executive head of state, and (iv) Douala as the administrative capital. According to Joseph B. Ebune, Growth of Political Parties in Southern Cameroon, IgI6-Ig6o (Yaoundé, Centre d'édition et de production pour l'enseignement et la recherche, i992), Foncha had a secret meeting with Ahidjo prior to the Foumban conference in which private arrangements were negotiated between them, whereas George Ngwane claims in Anglophone File (Limbe, Pressbook, i994) that the Southern Cameroons delegation arrived while still divided over what form of government they really wanted. As such, the proposals of Bamenda were simply ignored and Ahidjo presented his document, which some members saw for the first time on the morning of the opening ceremony, including the leader of the opposition, Dr Emmanuel Endeley.

Because of the haste with which the deliberations were conducted, it was agreed that both delegations would meet later, which they did at Yaoundé in August I96I. But after Ahidjo had refused to consult the Southern Cameroons House of Assembly, his document became the country's federal constitution in October I96 I. Thus, instead of submitting the constitution 'for 
Ahidjo looked upon federalism as an unavoidable stage in the establishment of a strong unitary state, and employed various tactics to achieve this objective. After becoming President of the Federal Republic of Cameroon in October ig6r, he played anglophone political factions off against each other, eventually persuading them to join the Union nationale camerounaise (UNG), the single party formed in September i966, and was able to penalise any anglophone leader who remained committed to federalism. Hence his replacement of Augustin Ngom Jua by Solomon Tandeng Muna, a 'unitarist', as Prime Minister of the federated state of West Cameroon in 1968, and his creation of 'clients' by according top posts in either the government and/or the party to representatives of significant ethnic and regional groups in the anglophone region.

On 6 May i972, Ahidjo announced in the National Assembly that he intended to transform the Federal Republic into a unitary state, provided the electorate supported the idea in a referendum to be held on 20 May, thereby abrogating clause I of article 47 of the Foumban document which read: 'any proposal for the revision of the present constitution, which impairs the unity and integrity of the Federation shall be inadmissible'. Even if the constitution were to be amended it should not be done by referendum, because clause 3 of article 47 stipulated 'that proposals for revision shall be adopted by simple majority vote of the members of the Federal Assembly, provided that such majority includes a majority of the representatives... of each of the Federated States'. ${ }^{9}$ The autocratic nature of Ahidjo's régime helps to explain why the inhabitants of Cameroon voted massively for the draft constitution, and hence the immediate establishment of the United Republic of Cameroon.

\section{SOGIO-EGONOMIC AND POLITIGAL FAGTORS}

The President's justification for the 'glorious revolution of 20 May I 972 ' was that federalism fostered regionalism and impeded economic development. A growing number of articulate anglophones, however, were inclined to attribute the emergence of 'regionalism' and lack of progress not to federalism per se, but rather to the hegemonic tendencies

ratification to the people of Southern Cameroons through Parliament or a Referendum', Ahidjo had it 'merely imposed on them'. See C. A. Taku, For Dame Lynda Chalker \& Other Anglophone Cameroonian Notes (Aba, Iduma Industries (Nigeria) Ltd, I996), p. I4.

9 A. W. Mukong (ed.), The Case for the Southern Cameroons (Yaoundé, Cameroon Federalist Committee, I990), p. I8. 
of the francophone-dominated state. They started to resent their region's loss of autonomy and the allegedly subordinate position of the anglophone minority in the unitary state. Their numerous grievances were mainly of a political, economic, and cultural nature: notably their under-representation and inferior rôle in national decision-making councils; the neglect of their region's infrastructure and the rape and drain of its rich economic resources, especially oil, by successive francophone régimes; and the attempts at 'frenchification' ${ }^{10}$

To reduce the growing dangers of united anglophone action, Ahidjo decided to divide the erstwhile federated state of West Cameroon into two Provinces, albeit well aware of the internal contradictions within the anglophone community between the coastal/forest people in the South West Province and the grassfield people in the North West Province. The former had acquired a head start over the latter by being exposed to early contacts with western trade, religion, and education. The intelligentsia that emerged in the coastal areas, notably among the Bakweri, had quickly risen to the forefront in the nationalist struggle and dominated the anglophone political scene for a number of years.

But during the late i 95 os a fierce struggle took place between the two major parties in the British trust territory about the political future of the Southern Cameroons: the South West-based Kamerun National Congress (KNC) led by Emmanuel Endeley, and the North Westbased Kamerun National Democratic Party (KNDP) led by John Ngu Foncha. Broadly speaking, the former championed the cause for integration with Nigeria while the latter crusaded for secession from Nigeria, and eventual reunification with the Republic of Cameroon. ${ }^{11}$ Following a narrow election win in I957, Endeley was installed as first

\footnotetext{
10 For the numerous anglophone complaints, see, for instance, All Anglophone Conference (AAC), The Buea Declaration (Limbe, Nooremac Press, I 993); Southern Cameroons National Council (SCNC), 'The Buea Peace Initiative', in Cameroon Post (Yaoundé), 20-27 April i 994; and Francis B. Nyamnjoh (ed.), The Cameroon G. C. E. Crisis: a test of anglophone solidarity (Limbe, Nooremac, I 996) and Mass Media and Democratisation in Cameroon (Yaoundé, Friedrich-Ebert Foundation, I 996), pp. 38-49. For a perspective by someone who had previously held several important government posts, see Solomon Tandeng Muna, 'Original Version of the Memorandum Addressed to President Biya in January I 984 on "The Anglophone Problem", , I984. And for an elaborate presentation of the anglophone problem to francophone newsmen, see $\mathrm{La}$ Nouvelle expression (Douala), I $3^{-1} 7$ January i 994 , being almost entirely devoted to the AAC's spokesman, Dr Simon Munzu's 'spécial club de la presse', dubbed: 'çe que veulent les anglophones'.

11 Of course, the actual situation was more complex. Endeley, for example, had moved from a pro-reunification stand towards a more positive view on integration into Nigeria when the Southern Cameroons became a region within Nigeria, which meant that the inhabitants could rule themselves, maintain their ties to the British inheritance, and avoid the violence and chaos of civil war in francophone Cameroon. See, for instance, Bongfen Chem-Langhëë, 'The Road to the Unitary State of Cameroon, I959-1972', in Paideuma (Stuttgart), 4I, I995, pp. I 7-25.
} 
Prime Minister of the Southern Cameroons in I958, but lost this post to Foncha in 1959.

During the I96I UN plebiscite the inhabitants of the South West showed considerable sympathy for alignment with Nigeria, but the choice for Cameroon prevailed, mainly on the strength of votes in the North West, where the following song was composed immediately after the plebiscite: 'Foncha has walloped Endeley. Foncha has walloped Endeley. If Foncha hadn't been there, Endeley would have sold us.' Strikingly, 30 years after the event, the text of this song was changed: 'Foncha trounced Endeley. Foncha trounced Endeley. If Foncha hadn't trounced Endeley, we wouldn't have been sold.' ${ }^{\prime 2}$

Since the early ig6os the North West élite has continued to play a dominant socio-economic and political rôle in both provinces, and its acquisition of the best jobs and lands in the South West has provoked strong resentment. ${ }^{13}$ The organisation known as the South West Elites Association (Swela) looks back in anger at the catalogue of victimisations at the hands of the KNDP, including the transfer to the North West of infrastructure meant for the South West, and the Foncha régime's associated 'deliberate' retardation of development projects and foreign aid. ${ }^{14}$ Such sentiments have been intensified by the fact that the 'entrepreneurial' North Westerners have gradually succeeded in dominating most sectors of the South West economy, in particular trade, transport, and housing. Some resent the fact that Simon Achidi Achu became Prime Minister in I 992 on the strength of the anglophone lobby, only to turn around and allegedly 'insult' the South West by filling key positions in his office with North Westerners exclusively.

The implications must also be considered of the massive labour migration from the North West to the South West, where a plantation economy was established during the German colonial era at the turn of the century. Pro-government Swela politicians and administrators have used the presence of so many workers from the North West to explain all political disturbances in their province, even going as far as insinuating, as did Governor Oben Peter Ashu in a Radio Buea interview after the January I 996 municipal elections, that the poor performance in the Fako division by the ruling Rassemblement démocratique du peuple camerounais (RDPG) could be attributed wholly to the 'settler population' who voted for the opposition. ${ }^{15}$

\footnotetext{
12 Cameroon Life (Buea), I, 8, ig9ı, p. го.

${ }^{13}$ See Ndiva Kofele-Kale, Tribesmen and Patriots: political culture in a poly-ethnic African state (Washington, DG, I98I).

${ }_{14}$ Swela's magazine, The Oracle (Limbe), April i 992, p. 35.

${ }^{15}$ The Herald (Yaoundé), 29-30 January I 996, p. 3.
} 
Lack of unity and severe repression precluded anglophone leaders from openly expressing criticisms about francophone domination until I982, when Paul Biya took power, but in the wake of his introduction of a limited degree of liberalisation they began voicing their longstanding grievances. In 1983 the Government promulgated an order modifying the anglophone General Certificate of Education (GCE) examination by making it rather similar to the Baccalauréat, and the ensuing demonstrations and boycott of classes were repressed by police brutality at the University of Yaoundé and in urban centres in anglophone Cameroon. ${ }^{16}$ In I 984 the Government changed the official name of the country from the 'United Republic of Cameroon' to simply the 'Republic of Cameroon' despite strong protests that this was what independent francophone Cameroon had been called by Ahidjo before reunification. In i 985 a prominent anglophone lawyer, Fon Gorji Dinka, was arrested after distributing a statement declaring the Biya Government to be unconstitutional and calling for the Southern Cameroons to become independent and rebaptised as the Republic of Ambazonia. ${ }^{17}$ Almost concurrently, two memoranda submitted to the Bamenda congress of the ruling UNC by members of the North West and South West élites resident in Douala drew attention to the plight of the anglophone minority, and highlighted that it felt sidelined from political power. ${ }^{18}$

Other factors fuelled frustration with the francophone-dominated state in the late ig8os, notably the increasing monopolisation of key posts by members of the President's ethnic group who appeared to be much bolder in staking out claims on the state's resources than had Ahidjo's barons. As of August I 99 I, according to Joseph Takougang, 37 of the 47 senior préfets were Beti, as were three-quarters of the directors and general managers of the parastatals, and 22 of the 38 high-ranking bureaucrats who had been appointed in the newly created office of the Prime Minister. ${ }^{19}$

In addition, there was the deteriorating economic crisis which

\footnotetext{
${ }^{16}$ For a detailed and documented account of what happened during I983, see Nyamnjoh (ed.), op. cit. pp. 19-68.

${ }_{17}$ See Fon Gorji Dinka's 'The New Social Order', dated 20 March I985, addressed to H.E. Comrade Paul Biya at the Bamenda CNU Congress, and his accompanying letter: 'Your Excellency, find enclosed an address which I had thought could be delivered at the Congress, and which could transform the Congress into a forum for the reconstruction of our institutions, those of Ahidjo having been peacefully swept away by God in his mysterious way'.

${ }^{18}$ For an elaborate and critical comment on these documents - to be found in Mukong (ed.), op. cit. - largely suspected among anglophones to have been sponsored by senior francophone officials, see Stephen Mungwa Tebi, Cameroon and a New Militantism: the faces behind the mask (1985).

${ }^{19}$ Joseph Takougang, 'The Demise of Biya's New Deal in Cameroon, I991-1992', in Africa Insight (Pretoria), 23, 2, I993, pp. 9I-IoI.
} 
anglophones were inclined to attribute first and foremost to the corruption and mismanagement of Biya's régime. ${ }^{20}$ They claimed that their region had failed to benefit from its rich oil resources, and criticised the absence of increased investments in its ailing economy and neglected infrastructure. Oil revenues were alleged to be used by those in power to feed 'the bellies' of their allies, ${ }^{21}$ and to stimulate the economy in other regions. The Société nationale de raffinage (Sonara), the oil refinery near Limbe (or Victoria as some prefer to call it again), continued to be headed and predominantly staffed by francophones. There was also great anxiety in anglophone Cameroon that its major agro-industrial enterprises, especially the Cameroon Development Corporation (CDC) and Plantations Pamol du Cameroun Ltd (Pamol), would be either liquidated or sold to francophone or French interests during the ongoing structural adjustment programme. ${ }^{22}$

\section{THE GROWTH OF ANGLOPHONE OPPOSITION}

Not surprisingly the first opposition party in the country appeared in anglophone Cameroon during the growing economic and political crisis. In I990 the Social Democratic Front (SDF) was formed at Bamenda, the capital of the North West Province. Its chairman was John Fru Ndi, a book-dealer by profession, who was to achieve great popularity among the urban masses because of his courage and populist style of leadership. After the massive rally to launch the SDF in May had ended in the deaths of six young anglophones, the state-controlled media tried to deny the Government's responsibility for this bloody event and to distort the facts. ${ }^{23}$ Leading members of the RDPG strongly condemned the anglophones for this 'treacherous' action, and their reaction to this peaceful demonstration shocked many in the country.

\footnotetext{
${ }^{20}$ For more on the Biya régime's corruption, mismanagement, tribalism, and other excesses as seen by an anglophone, see Rotcod Gobata, The Past Tense of Shit (Limbe, Nooremac Press, 1993), and his follow-up volume, I Spit on Their Graves (Bellingham, Kola Tree Press, I 996).

21 The politics of 'scratch my back, I scratch yours' and 'politics na njangi' - both meaning, 'one good turn deserves another' - had been vulgarised by the ruling RDPC, especially after a North Westerner, Simon Achidi Achu, had become Prime Minister in I992. Following his replacement in September 1996 by a South Westerner, Peter Mafany Musonge, the latter declared during a reception at Buea: 'President Biya has scratched our back, and we shall certainly scratch the Head of State's back thoroughly when the time comes' - meaning that South Westerners should resolve to manifest their total support and allegiance to the President who had appointed Musonge. See Cameroon Post, I 2-18 November i 996.

${ }^{22}$ See Piet Konings, 'Agro-Industry and Regionalism in the South West Province of Cameroon During the National Economic and Political Crisis', in Paul Nchoji Nkwi and Francis Beng Nyamnjoh (eds.), Regional Balance and National Integration in Cameroon: lessons learned and the uncertain future (Yaoundé, ASC/ICASSRT, I997), pp. 289-305.

${ }^{23}$ Nyamnjoh, op. cit. pp. 27-8.
} 
In June the anglophone architect of the federal state resigned as the First Vice-President of the RDPG. As Foncha explained:

The Anglophone Cameroonians whom I brought into union have been ridiculed and referred to as 'les Biafrais', 'les ennemies dans la maison', 'les traitres' etc., and the constitutional provisions which protected this Anglophone minority have been suppressed, their voice drowned while the rule of the gun replaced the dialogue which the Anglophones cherish very much. ${ }^{24}$

Under considerable internal and external pressures, the Government introduced a greater measure of political liberalisation. In December I990 it announced the advent of multi-partyism, as well as a certain degree of freedom of mass communication and association, including the holding of public meetings and demonstrations. ${ }^{25}$ As a result, several political parties, pressure groups, and private newspapers were established in Cameroon which began to express and represent anglophone interests. ${ }^{26}$

Subsequently, the SDF spread its influence to the South West and soon became the major opposition party in anglophone Cameroon. Nevertheless, the élite in the province continued to be suspicious of the aspirations of the SDF leaders for fear of renewed North West domination. With the exception of the Liberal Democratic Alliance (LDA), which has attempted, with marginal success only, to become a serious political formation, the South West has failed to produce a strong and credible party, mainly because of personal animosities. Indeed, the current leadership struggle in the LDA between Mola Njoh Litumbe and Lydia Belle Effimba is but a further indication that the élite in the South West has yet to come up with an effective alternative to the SDF. ${ }^{27}$

The leaders of the SDF helped to turn the anglophone region into a veritable hot-bed of rebellion, organising several serious confrontations with the régime in power, especially during the I99 I-2 'ghost town' campaign. ${ }^{28}$ The impact of this on the anglophone community was particularly visible during the ensuing presidential elections, when Fru

\footnotetext{
${ }^{24}$ John Ngu Foncha's letter of resignation from the RDPC is reproduced in Mukong (ed.), op. cit. p. I 55

${ }^{25}$ Société de presse et d'éditions du Cameroun, Cameroon. Rights and Freedoms: collection of recent texts (Yaoundé, Sopecam, i991).

${ }^{26}$ Nyamnjoh, op. cit. pp. 38-49.

27 For reports on the leadership struggle in the LDA, see Cameroon Post (Yaoundé), I6-22 April I996, and The Rambler (Yaoundé), 3o April-6 May i 996.

${ }_{28}$ This was the period from April I99I to January I992 when the radical opposition issued calls, ultimatums, tracts, etc., asking the public to immobilise the economy by staying indoors, blocking streets, refusing to pay taxes and bills, and boycotting the markets and offices. The 'ghost town' campaign aimed at forcing the Biya Government to hold a Conférence nationale souveraine. See Célestin Monga, La Recomposition du marché politique camerounais, I99I-1992 (Douala, I993).
} 
Ndi received respectively $86 \cdot 3$ and $5 \mathrm{I} \cdot 6$ per cent of the votes cast in the North West and South West Provinces. It is hardly surprising that the declared victory of Biya in October 1992 was a traumatic experience in anglophone Cameroon, with violent protests against his 'theft of Fru Nidi's victory' throughout the North West. The President then imposed a state of emergency on this province for three months, and Fru Ndi was kept under surveillance in his house in Bamenda. ${ }^{29}$ Whereas the United States, Germany, and the European Community denounced the fraudulent elections and the state of emergency in the North West and threatened to abandon their aid programmes to Cameroon until 'there was a clear advancement in the democratic process', the French continued to support Biya who appeared to be willing to safeguard their interests in Cameroon.

Paradoxically, although the SDF and Fru Ndi have contributed immensely to anglophone consciousness and action, the party increasingly presented itself as a 'national' organisation, evidenced by a growing number of francophone supporters, most of them originating from the neighbouring West and Littoral Provinces. The SDF appears to have adopted a rather ambivalent attitude towards calls from newly emerging pressure groups for a return to the federal state. Its 1992 national convention at Bamenda emphasised 'devolution of powers', and 'decentralisation' was the rhetorical focus the following year at Bafoussam, where not once was the word 'federalism' used by Fru Ndi. ${ }^{30}$ Although SDF members have been given the green light to belong to any anglophone movement, it would appear that the party is losing its initial appeal for English-speaking Cameroonians, because of its half-hearted stand as regards the 'anglophone problem'.

In fact, following political liberalisation in r 990, several associations and pressure groups were created or reactivated by anglophone élites to represent and defend their interests. Some, notably the Free West Cameroon Movement (FWCM) and the Ambazonia Movement (AM) of Fon Gorji Dinka, advanced outright secession, but most initially championed a return to the federal state, especially the Cameroon

\footnotetext{
${ }^{29}$ For a government account of the violence that took place after the presidential elections, and their aftermath, see Cameroon Tribune (Yaoundé), 26 and 29 October I 992, and the Ministry of Communication's white paper on 'Human Rights in Cameroon', published in November I 993. For a detailed alternative account, see Boh Herbert, Cameroon: state of human rights violations following October II presidential elections (Bamenda), io November 1992. The US Department of State's Country Reports on Human Rights Practices for 1992 (Washington, DC, February I993), pp. $3^{\mathrm{I}-4 \mathrm{O}}$, is also relevant.

${ }^{30}$ Cf. Milton Krieger, 'Cameroon's Democratic Crossroads, I990-4', in The Journal of Modern African Studies (Cambridge), 32, 4, December 1994, pp. 6o5-28.
} 
Anglophone Movement (CAM) and the All Anglophone Congress (AAC). Other pro-federalist organisations with a more restricted agenda included the Teachers' Association of Cameroon (Tac), the Confederation of Anglophone Parents-Teachers' Association of Cameroon (Captac), and the Cameroon Anglophone Students' Association (Cansa). In I993 they forced the Government to create a General Certificate of Education Board, and this signified an important victory for the anglophones in their ten-year-old struggle against determined efforts to destroy the GCE. ${ }^{31}$

These associations and pressure groups have regularly promoted demonstrations, strikes, and boycotts in their fight against the francophone-dominated unitary state, and the participation of various strata of the population demonstrates that the 'anglophone problem' is no longer to be perceived as simply and solely an élitist concern. Interestingly, these actions are partly directed against the discourses, myths, and symbols publicised by the régime in power. Anglophone movements have boycotted the celebration of the national feast day on 20 May, the 'day of the 1972 glorious revolution', declaring it a 'day of mourning' and a 'day of shame'. ${ }^{32}$ They have instead called upon anglophones to celebrate the 'day of independence' on I October and the 'day of the plebiscite' on i I February. On these feast days during I 992-3 attempts by CAM activists to hoist the federation flag were reportedly answered by the police with 'extreme brutality' ${ }^{33}$

In addition, there are increasing references to the "Southern Cameroons' by those who allege that the proper procedures for the enactment and amendment of the federal constitution were not followed by Ahidjo. ${ }^{34}$ From this perspective, some anglophones claim that they are living in a pre-reunification trust territory, and the flag of the United Nations has consequently been seen in recent years as a symbol of their belief in the continuing responsibility of the UN for the Southern Cameroons. ${ }^{35}$ Although the provocative reintroduction of this terminology has the advantage of reminding the inhabitants about the historical foundation for their anglophone identity, Luc Sindjoun has rightly observed that anglophone identity can actually only be claimed by inhabitants belonging to one of the territory's 'autoch-

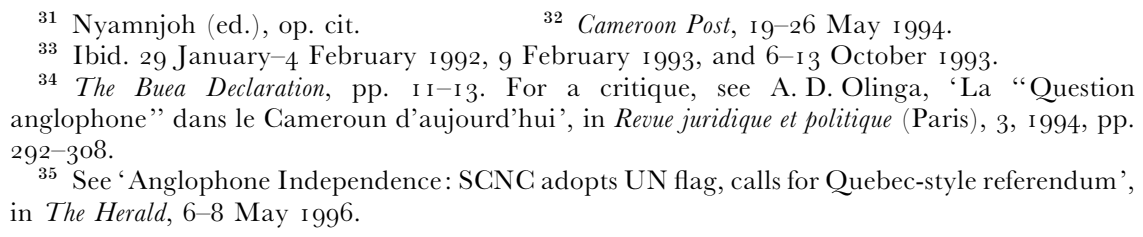


thonous' ethnic groups, a distinction which tends to exclude immigrants from Southern Cameroons citizenship, ${ }^{36}$ and which makes being 'anglophone' more of a geographic and administrative reality than a cultural one. Hence the references made to the imagined 'eleventh province' for those who are seen and treated as 'francophones of anglophone culture'. ${ }^{37}$

A major challenge to the francophone-dominated unitary state occurred during the Tripartite Conference convened by President Biya from 30 October to i 8 November i 99 I. Although representatives were not selected on a bicultural basis, four anglophones were able to impress on their francophone counterparts that it was time for Cameroon to return to the Foumban federal arrangements of Ig6I. Sam Ekontang Elad, Simon Munzu, and Benjamin Itoe, all from the South West, as well as Carlson Anyangwe from the North West, virtually torpedoed the proceedings by coming out with the EMIA constitution (named after their initials), which called for a West Cameroon state in a loose federation. ${ }^{38}$ They went on to convene the All Anglophone Conference (AAC) following the régime's announcement in March I 993 of a national debate on constitutional reform, and the next month over 5, ooo members of an 'All Anglophone Congress' met at Buea, the ex-capital of the Southern Cameroons, 'for the purpose of adopting a common anglophone stand on constitutional reform and of examining several other matters related to the welfare of Ourselves, our Posterity, our Territory and the entire Cameroon Nation'. ${ }^{39}$

The Buea Declaration listed multiple grievances about francophone domination and called for a return to the federal state. ${ }^{40}$ Like previous documents written by similar pressure groups, ${ }^{41}$ it tended to blame the wicked francophones as a whole for the plight of the poor anglophones, and compared both in rather idealised terms: the former, in full solidarity, agree among themselves to oppress the latter who, by their

\footnotetext{
${ }^{36}$ Luc Sindjoun, 'Rente identitaire, politique d'affection et crise de l'équilibre des tensions au Cameroun', in Afrique politique (Paris), forthcoming.

${ }^{37}$ Indeed, in June 1995 , the national radio carried an announcement on the creation of 'une association des francophones de culture anglophone'.

${ }^{38}$ See Cameroon Post, I-7 June i993, for the full text of the EMIA constitution.

39 The Buea Declaration, p. 8.

${ }^{40}$ Realising how 'ignorant' many francophones were about 'the history of the political union between the Southern Cameroons and La République du Cameroun', and how little they knew about federalism, Carlson Anyangwe and others gave themselves the task of educating the general public on 'the anglophone problem' and 'the federal option'. See Cameroon Post, 27 October-3 November 1993 .

${ }^{41}$ See, for instance, Mukong (ed.), op. cit., and Anglophone Patriotic Alliance, 'The Restoration of the State of West Cameroon', in The West Cameroon Fournal (Bamenda/Victoria), I99I, pp. I I-I 8.
} 
very nature, are peace-loving, open to dialogue, and committed to freedom. ${ }^{42}$ Of course, this demagogic approach, which is commonplace in ethnic discourse, serves to emphasise the 'insurmountable' dichotomy that justifies the AAC call for autonomy. This approach may be efficient in mobilising anglophones but has hardly helped the struggle against their 'real' enemy, the francophone-dominated unitary state which has allies and opponents in all parts of the country. In addition, it denies the existence of various ethnic links, and creates serious obstacles to any francophone sympathy for the anglophone cause. $^{43}$

In May ig93 the 65-member Anglophone Standing Committee established by the AAC submitted a draft constitution which would provide for major political, financial, and fiscal autonomy for the two federated states, for the provinces inside both, and for the communities inside each province. There would be the usual separation of powers between the executive, legislative, and judiciary, and a senate and national assembly for each federated state, as well as a rotating presidency for the Federal Republic, whereby after at most two consecutive mandates of five years an anglophone would succeed a francophone (or vice versa). This proposal was even reiterated for each of the federated states to ensure alternation between the provinces (obviously with the South West/North West divide in mind). ${ }^{44}$

Confronted with the Government's persistent refusal to discuss the AAC constitutional proposals, one of the most important associations affiliated to the AAC declared itself in favour of the 'zero option' on 3 December I 993 -i.e. total independence for the Southern Cam-

\footnotetext{
${ }^{42}$ V. E. Ngome claims in his article on 'Anglophobia', published in Focus on Africa (London, BBC African Service), 4, 3, I 993, pp. 27-9, that 'Anglophones see Francophones as fundamentally fraudulent, superficial and given to bending rules: cheating at exams, jumping queues, rigging elections and so on... The Francophones are irked by what they see as the anglophone air of selfrighteousness and intellectual superiority'. Quoted by Richard Fardon, "Destins croisés". histoires des identités ethniques et nationales en Afrique de l'Ouest', in Politique africaine (Paris), 6I, March i996, p. 93

${ }^{43}$ Indeed, because of such collective condemnation the French-language newspapers have been quite reluctant to admit the existence of an 'anglophone problem' in Cameroon. See, for example, La Nouvelle expression, I $3^{-1}$ I January i 994, pp. I-3, for the hostile reception experienced by Simon Munzu when trying to explain to francophone journalists and intellectuals the 'anglophone problem'. It is only recently, thanks to the trivialisation of the whole idea of minorities in the 1996 constitution, that the francophone press appears to be waking up to the concerns of the anglophone minority. See La Nouvelle expression. Dossiers et documents (Douala), 23 May i996, pp. I-28, devoted entirely to 'Minorités, autochtones, allogènes et démocratie' in Cameroon.

${ }^{44}$ The full text of the draft (EMIA) constitution was only released when Simon Munzu, Ekontang Elad, and Carlson Anyangwe realised that the other members of the reform committee set up by President Biya in May r 993 were impervious to any ideas on federalism.
} 
eroons. ${ }^{45}$ The CAM's shift from federalism to secession was more or less adopted during the Second All Anglophone Conference (AAC II), which had been organised in Bamenda from 29 April to 2 May I 994, ${ }^{46}$ when it was decided that if the Government 'either persisted in its refusal to engage in meaningful constitutional talks or failed to engage in such talks within a reasonable time', the Anglophone Council should 'proclaim the revival of the independence and sovereignty of the Anglophone territory of the Southern Cameroons, and take all measures necessary to secure, defend and preserve the independence, sovereignty and integrity of the said territory'.

The Bamenda Proclamation added that following the declaration of independence, the Anglophone Council should 'without having to convene another session of the All Anglophone Conference, transform itself into the Southern Cameroons Constituent Assembly for the purpose of drafting, debating and adopting a constitution for the independent and sovereign state of the Southern Cameroons'. Delegates voted to replace the AAC with the Southern Cameroons Peoples Conference (SCPG), and subsequently the Anglophone Council was in August rg93 rebaptised as the Southern Cameroons National Council (SGNG).

SOME INTERNATIONAL IMPLICATIONS

The Anglophone Standing Committee and the SCNC have made strenuous efforts not only to secure the wholehearted backing of the anglophone community for their strategies to create a federal or an independent Southern Cameroons state, but also to gain international support for their cause. ${ }^{47}$ The delegations sent in 1995 to the United Nations to protest against 'the annexation of its ex-Trust Territory, the Southern Cameroons', were following the example of Fon Gorji Dinka,

\footnotetext{
45 Cameroon Post, I-8 December i 993, pp. 7-1 o, and Cameroon Life (Buea), 2, io October I 993.

${ }^{46}$ Elad declared in an interview with Cameroon Post, 6-13 April I 994, that 'Zero option remains a principle and a clear option that Southern Cameroonians will consider at AAC II in Bamenda'.

${ }^{47}$ For more information about this diplomatic offensive see, for example: 'SCNC Delegation Leaves for UN, UK: constituent assembly envisaged', in Cameroon Post, 24-3 I May i 995; 'SCNC UN Mission Back Today: Southern Cameroons tables formal request for independence', in ibid. 26 June-3 July i 995 ; 'SCNC Homecoming: la République ordered out of Southern Cameroons', in ibid. 3-Io July r 995; 'Is Cameroon admissible?: Commonwealth team arrives to assess human rights record', in ibid. 24-3 I July i 995; 'Anglophone Problem: shouldn't Biya now open debate?', in The Herald, I0-I2 July I995; 'Commonwealth: delegation returns in total disappointment with Biya regime' and 'Commonwealth Admission: anglophone factor is inevitable', in ibid. 3 I July-2 August I 995; and 'SCNC Writes to UN Secretary-General: calls for intervention to avert catastrophe!', in ibid. 7-1o September 1995.
} 
as well as Albert Mukong, one of the most militant opponents of the régime and a leading member of CAM, who had petitioned the UN during the rg8os and early iggos to intervene on behalf of the anglophone minority. The co-option of Ngu Foncha and Solomon Tandeng Muna in the SCNC's delegation sent to New York was of considerable importance, since they are widely regarded as the anglophone architects of respectively the federal and the unitary state. Rites were performed to celebrate their return to the Southern Cameroons when they crossed the river Mungo in July i 995, and the Fon of Bafut, an SCNG sympathiser, conferred the title of 'Lord' upon both in recognition of their symbolic rôle. ${ }^{48}$ These missions to the United Nations may not have yielded any tangible results, but they have given wide publicity to the anglophone cause and helped to discredit Biya's régime.

Although Cameroon had applied in 1989 for membership of the Commonwealth, it was not until June i 993 that the Secretary-General, Chief Emeka Anyaoku, visited the country to examine whether the Republic met the conditions for admission. He was then virtually 'hijacked' by anglophone pressure groups which succeeded in subverting the programme drawn up by the Government and in familiarising him with their plight. They pointed out that the nation they represented was able to meet the historical and linguistic conditions for admission, and that the Commonwealth should therefore reject the application of the Republic and seriously consider granting the Southern Cameroons either full membership or a special status.

During the October 1993 Commonwealth summit held in Nicosia, Cyprus, Cameroon's admission was postponed on the grounds that it failed to meet the criteria for membership stipulated in the i 99 i Harare Declaration, namely: the establishment of a democratic system, good governance, and respect for human rights. The uninvited two-man delegation sent by the Anglophone Standing Committee lobbied some of the participants intensively, making them more aware of the Biya régime's persistent oppression of the anglophone minority, and undoubtedly influenced their eventual decision to postpone the country's admission.

Cameroon failed to achieve any democratic advancement in the next two years but became a member of the Commonwealth on I November I 995. It is widely believed in anglophone circles that Nigeria's positive attitude towards admission may have been due to the 'deal' made by

${ }^{48}$ See 'SCNC Homecoming', in Cameroon Post, 3-Io July and Io-I 7 July i 995. 
Biya and Sani Abacha to defend each other against international criticisms of their régimes. Other Commonwealth countries, including Britain which has often professed to be sympathetic to the anglophone cause, followed Nigeria's lead and voted in favour of Cameroon's admission. ${ }^{49}$ The argument that this would bring pressure to bear upon the Government to introduce political reforms was supported by the chairman of the SDF, Fru Ndi, although SCNG leaders have deeply regretted Cameroon's admission. The latter appeared to have adopted a new strategy when they pleaded during the November i 995 summit at Auckland, New Zealand, for a Quebec-style independence referendum for the Southern Cameroons, and filed an application for separate membership, even though the Commonwealth, as an association of sovereign and independent states, is usually reluctant to grant admission to 'separatist movements of minority groups'. 50

There is no doubt that France has strongly supported Cameroon during several economic and political crises. Besides the various agreements of co-operation between the two countries, there are other factors to explain the French strategy. There is the apparent concentration of organised opposition around a 'hard' anglophone core, not least since the chairman of the SDF has never concealed his resentment about French neo-colonialism and his pro-American stand. Fru Ndi's anti-French rhetoric coupled with his call for a boycott of French goods was not well received in Paris. Moreover, the AAC draft federal constitution has been regarded as a threat to France's 'superior' interests in Cameroon, and it continues to be widely believed that American decision-makers in Washington are exerting too great an influence on the policies not only of the International Monetary Fund (IMF) and the World Bank, but even those of the anglophone opposition.

Some changes have occurred in French thinking partly because of growing dissatisfaction with the Biya régime's economic and political performance, as well as an increasing interest in certain Englishspeaking African countries, notably Nigeria and South Africa. A few months after arriving as French ambassador to Cameroon in I993, Gilles Vidal did what none of his predecessors had ever done previously:

\footnotetext{
49 The SCNC chairman, Ekontang Elad, however, claimed after the summit in Auckland in I 995 that Cameroon was admitted because no member-state of the Commonwealth opposed its admission, not because they voted in support.

50 See 'Commonwealth: SCNC application referred to I997; liaison office recommended', in The Herald, 20-22 November i 995, and 'Anglophone Independence: SCNC adopts UN flag, calls for Quebec-style referendum', in ibid. 6-8 May ig96.
} 
he visited Buea and Bamenda and conferred with anglophone leaders, including Ngu Foncha, and later organised a meeting with members of the Anglophone Standing Committee to familiarise himself with the objectives of the AAC. His successor, Philippe Selz, has also been careful to keep in touch with the opposition, even dining with the SDF leader, Fru Ndi, on his ambassadorial 'tour of French-sponsored projects' in the North West Province in April r $996 .{ }^{51}$

Cameroon's recent membership of the Commonwealth is one indication of a growing distance between France and her former colony, and another was the French President's decision not to visit Yaoundé during his African tour in I $995 .{ }^{52}$ Jacques Chirac is said to have lost patience with the slow and inconsistent pace of economic and political reforms in Cameroon, as well as being very critical of continuing large-scale corruption, and this may help to explain why even the May r 996 visit to Paris by President Biya is not felt to have done much to thaw the strained relations. Certainly he was disappointed to find himself welcomed at the airport by the Minister of Cooperation, and not Chirac, as must have been expected, even though the French President had so recently distanced himself from the Government of Cameroon by 'recognising the anglophone problem' and 'proposing dialogue... and a constitutional approach as solutions'.53 Matters were even exacerbated when Biya boycotted the December i 996 franco-African summit in Ouagadougou, Burkina Faso, that was attended by President Chirac.

The SCNC set I October I 996 for the declaration of independence of the Southern Cameroons, but the date came and passed with nothing but an 'Independence Day' address by its new chairman, Henry Fossung, in which he called upon Southern Cameroonians to use their 'national day' as 'a day of prayers', asking God 'to save us from political bondage', and reiterating that independence was 'irreversible and non-negotiable'. ${ }^{54}$

Although international recognition of an independent Southern

51 Cameroon Post, 23-29 April i 996, and The Rambler, 30 April-6 May i 996.

52 See 'En Tournée africaine J. Chirac ignore le Cameroun', in La Nouvelle expression, I I-I 4 July i 995 .

53 See Cameroon Post, i6-22 April i 996, for Chirac's appeal and CAM's reactions.

54 Ibid. 8-14 October I996, and The Witness (Bamenda), I 2-i 8 November i 996. Momentum had earlier been somewhat weakened by the departure of Ekontang Elad for treatment in the United States, and his ensuing replacement as chairman of the SCNC by the more moderate Henry Fossung, a former ambassador. See Cameroon Post, 4-9 June i 996, for 'Change at the Helm of SCNC: Elad dropped, Fossung is new chairman'. In addition, Carlson Anyangwe and Simon Munzu, the brains behind AACI and AACII, had left for jobs in Zambia and Rwanda, respectively. 
Cameroonian state is unlikely to occur, the SCNG hopes that its diplomatic offensive has at least raised external consciousness enough to make the Government think very hard about possible military intervention after the eventual declaration of independence. Nevertheless, it has never excluded the possibility of a 'long-drawn-out war' and hence the need to create 'defensive shields' in the Southern Cameroons, ${ }^{55}$ so that 'the brutal forces of the Republic with their incessant provocations will not deter us' ${ }^{56}$

REAGTIONS OF THE FRANGOPHONE-DOMINATED RÉGIME

Attempts have often been made to minimalise the anglophonefrancophone divide by emphasising that this did not exist during the German colonial era. At present, Cameroon is officially a bilingual and multi-cultural nation, which many regard as a safe guarantee for the preservation of its differential linguistic and cultural heritage. But according to the authors of the Bamenda Proclamation, the Biya régime has preferred

to feign ignorance of the anglophone problem ... to seek by diverse manoeuvres to create division within the anglophone nation with the aim of giving the false impression that there is no general consensus within it on constitutional reform.... and to accuse the All Anglophone Conference and its affiliated organisations unjustly and falsely of having adopted a secession of Anglophone Cameroon as their goal.

The Government has often stressed that the unitary state is the outcome of the massive vote of the Cameroonian people as voluntarily expressed during the 1972 referendum. In reply to the anglophone demand for a return to the federal state, Biya has claimed, like Ahidjo, that this tends to be costly, weak as far as state power is concerned, and divisive, provoking ethnic and regional sentiments rather than national consciousness. From the very start, the President has also tried to equate federalism with secession. While constantly declining to discuss the federal or so-called 'two-state option', he appears to be willing to concede a certain degree of decentralisation within the unitary state by means of the present ten provinces in Cameroon.

Biya has attempted to divide the anglophones, like his predecessor, often capitalising on existing contradictions between the North West

\footnotetext{
55 See The Herald, 6-8 November i 995, for Elad's admission of a war of independence.

${ }^{56}$ The SCNC chairman, Henry Fossung, declared in his New Year message to Southern Cameroonians that i 997 would be a 'turning point in our strategy'. Cameroon Post, 7-I 3 January I 997 .
} 
and South West élites. Some of the latter have been appointed to key positions in their province in response to complaints about North West domination. For example, Peter Mafany Musonge replaced John Niba Ngu as general manager of the CDC, Dorothy Njeuma was appointed Vice-Chancellor of the newly created anglophone University of Buea, and Becky Ndive was transferred from Yaoundé to head the Cameroon Radio-Television (CRTV) station in the South West. In addition, Biya has used his anglophone allies for the defence of the unitary state, and some have been adequately rewarded for their services. Indeed, many have blamed the leaders of the anglophone movements for their 'demagogic and irresponsible' calls for federalism or secession, and dispute their claim of being the 'spokesmen' of the English-speaking community, thereby leading to severe confrontations between the two camps.

Following the organisation of the AAC in April i993, there were attempts by certain members of the South West Chiefs Conference and Swela, who were known to be closely allied with the régime in power, to dissociate the South West from the deliberations and resolutions of the AAC and from the Buea Declaration. There was also a meeting of a previously little-known North West Cultural and Development Association (Nocuda) at Bamenda in May r993 to dissociate the province from the AAC by branding the latter as a South West affair. This gathering seems to have been organised by those North Western members of the RDPG who in the following year would actively work against holding AAC II in Bamenda in a bid 'to kill the Anglophone Dream'. ${ }^{57}$

In September i 993, nine representatives of the South West Chiefs Conference travelled to Yaoundé to pledge their unalloyed allegiance to President Biya. They told him that 'they were alarmed at the numerous demonstrations, blackmail, civil disobedience, rebellious attitudes and recurrent activities designed to destabilize the state and the government', and strongly condemned any attempt to partition Cameroon on the basis of anglophone and francophone cultures. They asked the Head of State to transform the present ten provinces into ten autonomous provinces, and drew his attention to the fact that after reunification the South West Province had been discriminated against in the distribution of 'strategic posts'. ${ }^{58}$

\footnotetext{
57 See Cameroon Post, 20-27 April r994; 29 April-i May r994; and 29 June-6 July r994; The Herald, 29 April-I May i 994 ; and The Messenger (Mutengene), 2 May I 994.

58 The Herald, 3-io November 1993.
} 
Following the military brutalities in the South West during the Government's 1993 anti-smuggling campaign, ${ }^{59}$ a split occurred in Swela which had been founded to promote the socio-economic and cultural development of the province and to combat its domination by the North West. On the one hand, there are those who maintain close links with Biya's régime and the RDPC, and who often display strong anti-North Western sentiments. The members of this group include older and younger RDPG barons, like Emmanuel Tabi Egbe, Peter Agbor Tabi, John Ebong Ngolle, Ephraim Inoni, and Caven Nnoko Mbele, as well as such important South West chiefs as Mola Samuel Endeley and Nfon Victor Mukete. They are opposed to a return to the federal state and champion the ten-state option, which would retain the present separation between the South West and North West Provinces, and thus safeguard the former's autonomy. ${ }^{60}$

By way of contrast, some Swela members are more critical of government policies and often allied to opposition parties, notably the Social Democratic Front. They advocate closer co-operation between the South West and North West élites as a necessary precondition for an effective representation of anglophone interests, and strongly support the demand for a return of the federal state. But in order to show the powerful nature of the pro-RDPC Swela, its secretarygeneral, Gaven Nnoko Mbele, was appointed government delegate for the Kumba urban council following the January ig96 municipal elections, while Martin Nkemngu, secretary-general of the pro-SCNC Swela, was transferred from Buea, where he was provincial head of the news agency known as Camnews, to Yaoundé as an ordinary member of staff with Sopecam. ${ }^{61}$

Since i 994 a number of South Western and North Western chiefs and members of the RDPC have repeatedly condemned the call for Southern Cameroons to be independent, appealing to the Head of State to employ every available means to defend the unitary state. ${ }^{62}$

\footnotetext{
59 The easy access offered by Cameroon's sea and river ports to and from the south eastern region of Nigeria explains why the South West Province has traditionally attracted informal, often illegal commerce between traders from the two countries. A significant number of basic consumer items sold in Cameroon are smuggled across Nigeria, often with the complicity of customs at the borders. Prior to the anti-smuggling campaign, most users of cars in the South West Province had acquired much cheaper fuel from Nigeria, a development which could not be condoned by the Cameroonian authorities, in dire need of liquidity from the sales of their own oil, especially following the crippling effect of the 'ghost town' campaign.

${ }^{60}$ See Weekly Post (Yaoundé), November i 994, for a comprehensive account of the pro-RDPC Swela's ten-state federation option.

${ }^{61}$ For an idea of the Swela 'war', see ibid. 26 January-2 February I995.

${ }^{62}$ See 'Pro-CPDM Chiefs Bargain Destruction of SGNG', in Cameroon Post, I 7-24 July 1995.
} 
Paradoxically, the 'anglophone problem' has enhanced the chances of such Biya loyalists being appointed to government posts which used to be reserved for francophones only. Obviously, the decision to enhance the position of anglophones in the state apparatus is designed to belie charges that they only play second fiddle in the francophone-dominated unitary state, and simultaneously to attract new members of the anglophone élite into the 'hegemonic alliance'.

In 1992 Simon Achidi Achu, a North Westerner, and Ephraim Inoni, a South Westerner, were appointed respectively as Prime Minister and Deputy Secretary-General in the Presidency of the Republic. Other highly placed anglophones, including Peter Abetty, John Ebong Ngolle, John Niba Ngu, Francis Nkwain, Peter Agbor Tabi, and Samuel Ngeh Tamfu, may also expect to be members of the delegations which are regularly sent from Yaoundé to contest the claims of the leadership of the anglophone movements and to defend the unitary state. It should, however, be noted that Biya's policy of allocating prestigious positions within the state apparatus to anglophones has also encouraged internal competition among these privileged allies. In fact, South Westerners still feel that they are underrepresented in the highest government offices and have constantly requested that a politician from their province should succeed Achidi Achu as Prime Minister. ${ }^{63}$

So when a South Westerner, Peter Mafany Musonge, was appointed in September i 996 to take over from Achidi Achu as Prime Minister and more South Westerners were maintained in key cabinet positions than North Westerners ${ }^{64}$ the former reportedly 'went wild with excitement and jubilation and loudly praised the Head of State' for having at last listened to the cry of despair of South Westerners, who for over 36 years were 'confined to the periphery of national politics and socio-economic development' ${ }^{65}$ In the words of Musonge himself, this being 'the first time in our history as a united nation that a South Westerner has been appointed Prime Minister', South Westerners had 'to come together to galvanise the second political awakening in the South West Province', and 'to strengthen our position and bargaining

\footnotetext{
${ }^{63}$ For example, after winning a seat in Mamfe during the 1996 municipal elections, the Minister of Higher Education, Peter Abgor Tabi from the South West, could not conceal his ambition to replace Achidi Achu when the Prime Minister was defeated in his home constituency in the North West. See The Herald, I-2 April and I I-I 4 April 1996.

${ }^{64}$ Cameroon Tribune (Yaoundé), 20 September and 2 October 1996

65 'Significance of P. M. Musonge's Appointment' by a member of the South West élite, Kome Epule, in The Star Headlines (Limbe), 20 November 1996.
} 
power'. ${ }^{66}$ At his RDPG congress in December i 996, Paul Biya further strengthened the position of the South Westerners by admitting more of them into the central committee of the party than North Westerners; and the 22-member political bureau formed after the congress included two South Westerners (John Ebong Ngolle and Dorothy Njeuma) and only one North Westerner (Samuel Ngeh Tamfu) ${ }^{67}$

And, last but not least, the Government has for years relied on a strategy of repression. It did not allow the convenors to hold AAC I on the premises of the University of Buea in I993, and the following year attempted to obstruct the organisation of AAC II on the grounds that the participants had come "together in Bamenda to declare secession' ${ }^{68}$ The leaders of the anglophone movements tend to be harassed by security forces, threatened with arrest, and subjected to travelling restrictions. ${ }^{69}$ Repression has increased with mounting threats of the proclamation of an independent Southern Cameroons, and SCPC rallies and demonstrations are officially banned in the anglophone provinces. ${ }^{70}$ Despite the intimidating presence of a large number of security forces, however, SCNC actions have continued; for example, during the so-called 'sensitisation tours' to urban centres in anglophone Cameroon, when the organisation's leaders informed the urban population of their programme and strategy, the military could often not stop them from entering the towns and addressing the crowds. ${ }^{71}$ Neither could the military prevent the SCNG 'signature referendum' conducted during September I995, when 300,000 anglophones

\footnotetext{
${ }^{66}$ For reports on (i) the reaction by South Westerners to the appointment of 'a son of the soil' as Prime Minister, (ii) how, thanks to Paul Biya, 'the South West Smiles... Again', and (iii) the grandiose reception they offered Peter Mafany Musonge in Buea, Lime, and Yaoundé, see The Herald, 2-3 October, I I-I 4 November, and 2-3 December 1996. Also The Star Headlines, 20 November I 996; Cameroon Tribune, I 2 November and 2 December i 996; and Cameroon Post, I $2-18$ November 1996 .

${ }_{67}$ Cameroon Tribune, 20 December i 996, and The Herald 22-24 December I 996.

${ }^{68}$ See Cameroon Post, 20-27 April r 994; The Herald, 28 April-1 May i 994; and Cameroon Post, 29 June- 6 July i 994

${ }_{69}$ According to the Governor of the South West Province, Oben Peter Ashu, the 'SCNC is ... an illegal pressure group which wants to turn Buea into a battle ground', and 'we must chase the leaders of that group out of this province'. Cameroon Post, io-1 7 July i 995.

${ }^{70}$ Ibid. 24-3 I July i 995 and The Herald, 3 I July-2 August i 995. Indeed, any gathering likely to bring together critically minded anglophones risks being banned. For example, in May i 996 the South West Governor banned without explanation the meeting to be chaired by Christian Cardinal Tumi in Buea that was to have launched Nyamnjoh's aforementioned publication, The Cameroon GCE Crisis: a test of anglophone solidarity. See Cameroon Post, 2 I-27 May 1996, and The Herald, 23-26 May i 996.

${ }^{71}$ Newspaper reports of these 'sensitisation tours' include 'SCNG Hits Kumba: 75000 jam town green', in The Herald, 3-6 August I994, and 'As Elites Condemn Military Occupation: SCNC plans operation storm Mamfe', in Cameroon Post, I4-2 I August 1995.
} 
rejected the unitary state in favour of total and immediate independence. $^{72}$

\section{GONGLUSION}

The highly centralised form of federalism experienced by Cameroon during $196 \mathrm{I}-72$ remained a historical and symbolical reference for the anglophone pursuit of self-determination and autonomy after the opposed creation of the francophone-dominated unitary state. In the wake of political liberalisation in the early ig9os, as this article has shown, anglophone interests came to be represented first and foremost by various associations and pressure groups that initially demanded a return to the federal state. It was only after the persistent refusal of the Biya Government to discuss this scenario that secession, which used to be covertly discussed by a limited few, became an overt option with mounting popularity.

With the exception of those who are closely allied to the régime in power, the anglophones have become increasingly aware of the importance of united action, and the positive response of concerned activists in both the South West and the North West to invitations to participate in AAC I and II is proof that the old provincial divisions have been somewhat reduced. The brutal clamp-down authorised in the South West during the r993 anti-smuggling campaign was a decisive factor in drawing several hesitant members of the élite there into the ranks of the pro-federal pressure groups; and not even the appointment in September I996 of a South Westerner as Prime Minister appears to have affected that-especially since Musonge made a 'false start' by appointing as chief of cabinet someone from the Littoral Province. ${ }^{73}$

The Government's continued denial of any 'anglophone problem' in Cameroon, and its determination to defend the unitary state by all available means, including repression, could lead to an escalation of anglophone demands past a point of no return.

\footnotetext{
${ }^{72}$ For details, see Cameroon Post, 29 May-4 June and 25 June-1 July r 996.

${ }^{73}$ After succeeding Achidi Achu in September 1996, Musonge proceeded to substitute key North Westerners in the Prime Minister's office with South Westerners, except for the all important position of chief of cabinet, which went to Pierre Moukoko Mbonjo from the Littoral Province. This was perceived as such a grievous mistake that in an editorial entitled 'Musonge Makes a False Start', in The Herald, i 8-2o October I 996, this South Westerner-owned newspaper expressed the widespread disappointment among the South West élite, calling on the Prime Minister 'to revert the act', and lamenting: 'What bad luck? We all petitioned and fought for the post, now Musonge is handing the fruits away. Isn't it a shame! Heads we lose, tails we lose!'
} 